\title{
STUDY OF THE CURRENT STATUS OF TRAINING OF APPLICANTS FOR HIGHER EDUCATION ON THE SPECIALTY "PUBLIC MANAGEMENT AND ADMINISTRATION"
}

\author{
Raisa Naumenko \\ Doctor of Science in Public Administration, Senior Researcher, Professor \\ Department of Management \\ Kyiv National University of Trade and Economics \\ 19 Kioto str., Kyiv, Ukraine, 02156 \\ naumenko_r@ukr.net
}

\begin{abstract}
The current state of the normative providing of introduction of new specialty "public management and administration" is analyzed in the article. The meaning of terms "public management and administration", "public governance", "public management" was revealed. The study identified key priorities for training applicants for higher education in specialty "public management and administration", among which a special place is occupied by harmonizing training standards for the level of training "Bachelor", "Master", "Doctor of Philosophy» (PhD). The article describes the principles enshrined in the Law of Ukraine "On Higher Education", such as transparency, independence of higher education, priority of universal values, unity of the national educational environment, universal access to education, the principle of international integration of the higher education, and democratic nature of education governance and institutional autonomy.

The study revealed a number of issues regarding the regulatory support of implementation of the new specialty "public management and administration". In particular, the analysis of the Law of Ukraine "On Higher Education" points to the need to review the whole range of existing programs and adapt their content to the requirements of the Association Agreement between Ukraine and the EU. There is an urgent need to improve educational programs as to the number of ECTS credits for competencies of graduates in terms of learning content, terms of learning outcomes, certification and quality control.

Creation of the new educational programs of universities aimed at ensuring conditions for the formation and development of professional competencies of bachelors and masters will enable them to work successfully in the field of public administration and management at the international, national, regional and local levels. Under the new paradigm, the main areas of university training seekers of higher education in the specialty "public management and administration" is the study of public managers, of public policy analysis; management of the economy; civil service; public administration and international development.
\end{abstract}

Keywords: applicant for higher education, public management and administration, public governance, public management.

\section{Introduction}

Modernization of the state management system and the modern approaches to the formation of professional competencies of managerial staff in the context of Association Agreement between Ukraine and European Union condition the increased requirements to the quality of higher education, especially to the preparation of the high education applicants on the specialty "public management and administration".

It must be noted, that for today our country has not enough specialists who understand the need for changes in Ukraine, have analytic knowledge and are able to adapt the regulatory acts of European Union to the Ukrainian realities. There are also the contradictions that flow from the needs and conditions of the labor market and also condition the difficulty of harmonization of legislation in the aspect of correspondence to the regularities in the sphere of higher education and to the national professional standards, especially, "Professions classification". 
The recent law of Ukraine "On Higher Education" [1] gave the impulse to the creation of standards, new programs and new conditions of preparation of the higher education applicants and to the determination of the standards of public management and administration based on the competence approach and use of the best practices of the advanced world experience. According to the decree of the Cabinet of Ministers of Ukraine from 29 April 2015 № 266 “On approval of the list of fields of knowledge and specialties of preparation of the higher education applicants" [2] and the new list of the fields of knowledge and specialties of preparation of the higher education applicants approved by the decree of MES of Ukraine from 6 November 2015 № 1151 [3], was introduced the new specialty "public management and administration" in the field of knowledge "management and administration". For today scientific communities actively discuss the problems of the absence of unified methodological approaches to the explication of the following notions: "public administration", "public governance", "public management". The question about the content of the new specialty "public management and administration" and structure of specialties and correspondent academic disciplines is also a controversial one. The problem of identification of the notions "public administration" and "state service" is also the subject of discussion while the regulatory field of Ukraine differentiates the state service and service in the local governance and does not offer the official interpretation of the notions "public management" and "public administration". So, we find it necessary to elaborate the unified approaches to the formation of categorical apparatus and regulation of the main terminology at the legislative level.

\section{Analysis of the literature and statement of the problem}

The first task of the higher educational institutions is the formation and preparation of the competent managers ready to perception and realization of the reformative transformations in the system of state management and local governance based on the new understanding and introduction of the innovative mechanisms of public management. Introduction of the modern bases of public management, public policy and the need for the new specialty 074 "public management and administration" in the field of knowledge 07 "management and administration" intensified scientific searches of the native and foreign researchers among which can be divided several scientists from the National academy of the state management, its regional institutions and other scientific and educational institutions of Ukraine.

It is worth noting, that in both Ukrainian and Western scientific communities the unified approaches to the theoretical-methodological grounding of public management are not elaborated for today. The public management is mainly considered as the field of theory and practice that includes the sphere of activity of the state institutions and deals with mainly internal management and the functions connected with it such as: planning, organization, control, regulation. But the questions connected with categorical apparatus and mechanisms of introducing in educational process of the higher educational institutions the specialty "public management and administration" still debatable.

Especially the question about using the term "public management" is considered in the works of German scientists (K. Pollitt and G. Bouckaert) from the positions of multidimensionality of this notion that includes the public activity of the state employees and politicians, organizational structures and procedures of state authorities. Public management is interpreted as the king of managerial activity connected with policy, law and civil society [4].

The problems of development and modeling of the public management based on introduction of the modern civilizational approaches to the management of society [5] and analysis of modernization of the new public management [6] is a subject of scientific studies of the foreign scientists.

The modern studies of theory and methodology of the public administration as the process of elaboration, acceptance and realization of managerial decisions [7], are directed on the searches for effective ways of services provision, social needs satisfaction, condition the objective necessity of the semantic filling of the category "public management" and giving the complex characteristic of all its subsystems and spheres of managerial influence [8]. 
So, the features of transition from the management of society to the public management is presented in the interpretation of notions and terms "public control", "public policy", "public management" [9-11], "public governance" and "public administration" [12].

\section{Aim and tasks of research}

Aim and tasks of research are in actualization of the scientists' attention to the debating theoretical-methodological questions as to preparation of the higher education applicants on the new specialty "Public management and administration" that is introduced in the educational process in the native higher educational institutions and in the grounding of the author's position as to terminological apparatus of the new specialty.

For attaining the set aim the following tasks were formulated:

1. To characterize the modern state of the normative support of introduction of the new specialty "public management and administration" and to generalize the scientific terminology on this problem.

2. To ground the scientific approaches to the necessity of the practical introduction of the specialty 074 "public management and administration" in the native higher educational institutions.

3. To define the node priorities of the university preparation of the higher education applicants in the field of public management at the levels "bachelor", "master", $\mathrm{PhD}$ and outline the prospects of the further effective development of the specialty "public management and administration" within realization of the state educational strategy.

\section{Materials and methods of research}

Theoretical and methodological base of research is the works of the native and foreign scientists on the questions of preparation of the higher education applicants on the specialty "public management and administration", native and foreign scientific periodical literature, internet-resources. In the process of solving the set tasks were used the methods of analysis and synthesis for understanding the current status of the normative support of introducing the new specialty "public management and administration" and method of the system generalization for revealing the essential contradictions of the given problem in the system of university education.

\section{Results of theoretical research of the given problem allow separate the effective ways of its elucidation}

The first one provides the generalization of the scientific approaches to the analysis of content and native terminology of the problem, the second one - the necessity of harmonization of legislation as to the correspondence to the regulations in the field of the higher education and to the national professional standards.

The third one connected with introduction of the educational complex of disciplines of the specialty "public management and administration" in the professional preparation of the higher education applicants and correlation between the specializations of this specialty.

Before coming to consideration of the node notion "public management and administration" let us consider the explications of the term "public sphere" in the dictionary editions and encyclopedias. Thus, the encyclopedic dictionary-directory "The new political vocabulary" interprets the term "public sphere" as the social space in which people (public) communicate and collaborate with each other and with the whole society for solving the social problems [10]. Accordingly, the public services are the services provided by the state authorities, local self-government, enterprises, institutions, organizations under their management. Sharov Y. P. [12].

According to A. Kolodiy [8], it is reasonable to interpret "public management" in the name of specialty as the general name for its two main types: public government and public administration. As to the differences between these types of management in the public sector, A. Kolodiy underlines, that "public administration" as a subspecies of the "public administration" includes consulting, organizational-regulatory activity and the public services provision and its subjects are the professionally prepared persons - public employees that realize these 
types of work in governmental, self-governmental and public structures. Alongside with the subsystem of the public administration (in hierarchical structures - above it) is placed the subsystem of governance: acceptance and realization of the socially important decisions on the different directions of public policy.

In the modern Ukrainian conditions, undoubtedly, must be also the specialization "local self-government" that will prepare specialists for the sphere of managerial activity that is at the stage of active reformation for today. And in final, takes place the traditional "public administration" (our former "state management" in the narrow sense, but for today not only in the state institutions) [8].

Public governance and public administration are the two types of managerial activity of the public authorities owing to which the state and civil society provide the self-guidance (self-governance) of the whole social system and its development in the certain defined direction [8]. It is the difference between the traditional political government and the new governance connected with the change of managerial paradigm in European and other developed countries of the modern world [10].

Public administration is the type of organizational-regulatory activity directed on preparation and introduction of the state decisions, staff management, providing services to the population. Public administration (state administration, according to the traditional post-soviet terminology) is the technical component of the political and public governance that must be realized on the professional (non-political) base, involving, if it necessary, the non-state partners for the collective solving of problems that appear in this sphere of managerial activity.

The main feature of the public administration as the type of managerial activity in the fact that unlike to the political and public government connected with making power decisions public administration is an activity of professional managers (officials, state employees) directed on the preparation of decisions and organization of their realization [10].

\section{Discussion of the results}

The necessity of reformation of the public management in Ukraine by the realization of the significant complex of the system reforms needs from the modern managers to possess the significant volume of innovative and analytic information.

The expedience of introducing in the educational process of the higher school the academic discipline "public management and administration" is determined by the need for scientifically grounded preparation of innovatively and creatively thinking competent specialists able to solve the managerial problems connected with the intensive development of our country effectively.

The educational MPA program is oriented on the balance between the necessary theoretical knowledge and processing of the practical cases.

That is why it is urgent to update the university educational programs and to orient the forces of the native higher educational schools on the organization of trainings and activities using the foreign language just for acquiring by the public managers the communicative skills according to European standards for the worthy positioning of the Ukrainian interests on the world scene. The following tendencies are observed in the development of the higher education: formation of the universities as the centers of continuous professional education; rise of the requirements to the applicants for the admission to the higher educational institution; change of the terms of study; rise of the requirements to the quality of teaching; processes of knowledge fundamentalization. Among them, in first turn, globalization, internationalization, regionalization, multiculturalism, social and professional mobility, integration of the science, education and practice.

The question of the necessity of introduction of the new specialty "public management and administration" in the higher educational institutions for acquiring by the bachelors and masters the new skills, knowledge and abilities on the questions of communicative technologies, public forms of management, electronic communication, anti-corruption presupposes the preparation of the new generation of specialists able to provide the improvement of availability and quality of administrative services, rise of the quality of making the managerial solutions with involving in 
these processes the experts, representatives of the civil society that allow guarantee the effective, transparent, open and flexible structure of the state service.

The law of Ukraine "On High Education" determines the requirements to the educational program: volume of ECTS credits, list of competences of graduate, normative content of preparation formulated in terms of the study results, attestation forms, systems of guaranteeing the quality.

Creation of the new educational university programs is aimed at guaranteeing conditions of formation and development in bachelors and masters of the program competences that allow them successfully work in the sphere of public management and administration at international, national, regional and local levels.

According to the new program of public management, the main directions of the university preparation of the public managers are defined as following: analysis of the public policy; economics of governance; state service in the public management; international public management and development.

The two-stage system of educational-qualifying levels according to the scheme "bachelor-master" is offered as the possible model. The first stage in the academic plan must fully provide the access to the second level of MA preparation. Alongside with it the education at the master level guarantees the right to continue the post-graduate education and to gain the $\mathrm{PhD}$.

The continuity in educational practice is provided also by the methodically and psychologically grounded formation of programs, textbooks, compliance with the sequence of movement from the simple to complicated problems at acquiring knowledge and organizing the independent students' work:

- principle of continuity of the process of acquiring the higher education. The system of higher education in Ukraine is constructed according to the principles of sequence that is provided by the internal unity of educational structure and coherence of the stages of educational process;

- principle of the state support of preparation of the specialists with the higher education for the priority fields of economic activity, directions of fundamental and applied scientific researches, scientific-pedagogical and pedagogical activity;

- state support of the educational, scientific, scientific-technical and innovative activity of the universities, academies, institutions, colleges, especially by giving benefits from the tax proceeds, duties and other compulsory payments to the higher educational institutions that realize such policy. The state guarantees the budget financing of scientific and scientific-technical activity at the expense of costs of the State budget of Ukraine; education;

- principle of favoring the realization of the state-private partnership in the sphere of higher

- principle of the openness of formation (development of academic freedoms, organization of educational process, scientific researches).

In the article 2 of the "World declaration on the higher education for XXI century: approaches and practical arrangements" is noted, that according to the Recommendation about the status of pedagogical staff of the higher educational institutions accepted by the General conference of UNESCO in November 1997, the higher educational institutions, their employees and students must "have the full academic freedom and autonomy that is understood as the complex of rights and duties, being at the same time completely responsible and answerable to society".

The state policy in the sphere of higher education in the conditions of integration to the European educational community is the totality of different arrangements, actions, decisions of the state authorities directed on realization of the wide-ranging reforms in this sphere that are carried out by the Ukrainian government and are interested not only for officials working in the system of education management but practically for all Ukrainian citizens of any age category (students, post-graduate students, audience of the different courses of additional education, programs of professional requalification united by the same aim - development of Ukrainian education.

The state is interested in modernization of the higher education because it is directly connected not only with the question of observance of the rights and freedoms of person and citizen, 
but also with the successful development of the Ukrainian economy, social well-being of nation and the state of national security.

The course on the priority of the sphere of higher education is realized by the state on the following directions:

- creation of the developed regulatory base, formation of the independent branch of legislation in education sphere (normative component of the state policy in education sphere);

- formation of the optimal structure of organization and management of education (organizational-managerial component of the state policy in education sphere);

- preparation of the highly professional scientific-pedagogical staff for the education sphere (staff component of the state policy in education sphere);

- strengthening of the connection between education and science (academic component of the state policy in education sphere);

- development of international contacts and academic mobility (international component of the state policy in education sphere).

For regulation of the actions realized within the state educational policy is used the programming method which result is the system of programs of the long-term development of higher education that are elaborated at the different levels (national, regional, municipal ones, at the level of educational institution). And the node program is, undoubtedly, the National specific program of the higher education development that determines the strategy of reforming the system of Ukrainian higher education and indicates the most important arrangements for its realization.

Principles that must be observed by the state at formation and realization of its educational policy and also at formation of legislation in the higher education sphere are fixed in the Ukrainian law "On Higher Education" [1]:

- furtherance of the stable development of society by preparation of the competitive human capital and creation of conditions for education during the life. This principle fixes framework within which the content of education is determined, the educational methods and the most important sets of educational policy are formed;

- availability of the higher education - this principle is one of the most important guarantees of realization of the constitution right to education. Each person not depending on sex, age, nation, religion, location, economic prosperity has the access to the higher education within framework fixed by law;

- independence of the higher education from the political parties, public and religion organizations (except the higher spiritual educational institutions); this principle is based on the optimal distribution of functions in the education management among the state authorities and the ones of HEI self-government on condition of university autonomy guaranteeing;

- principle of international integration and integration of the higher educational system of Ukraine in the European space of the higher education on condition of safekeeping and development of achievements and progressive traditions of the national higher school. According to Bolognese agreement, we must talk about the use of transparent schemes and stages of training specialists that will be open and equal for all countries [13]. Students obtain the rights to take part in formation of content of their own trajectory of education on condition of compliance with the requirement of the state educational standards of higher education.

Ukraine has chosen its own way of HEI autonomy defined by the Law "On Higher Education". That is why, since 2014 autonomy of educational institutions in Ukraine is the one of most important principles of the state policy in education sphere. Autonomy of the higher educational institution is considered as self-support, independence and responsibility of the higher educational institution in making decisions on the development of academic freedoms, organization of educational process, scientific researches, internal management, economic and other activity, independent selection and distribution of staff [1].

Provision of the main academic freedoms to the higher educational institutions is the common principle of educational legislation and is fixed in several international-legal documents of higher educational institutions. Giving the autonomy to higher educational institutions legislation gave them certain authorities that they had not yet. Management of the activity of 
autonomic HEI and its organization, widening of independence creates the new risks for them that inevitably needs the rise of the quality of managerial staff of institutions, universities and academies. Because of the direct connection between the legal status of HEI and the system of its management, the internal system of its management was cardinally transformed after giving the widen autonomy [9].

In UNESCO recommendation "On the status of scientific workers" [14] was fixed that academic freedom that is free dissemination of information about the results, hypotheses and critical statements is an integral part of scientific process. Within the existing legislation of Ukraine the higher educational institution elaborates and accepts status that fixes the main points that regulate its life activity. HEI has the significant authorities in the sphere of organizational-staff policy. But realizing the given authorities at introducing in the educational process the new specialty "public management and administration" HEI must be guided by its own established standards and quotas conditioned by the license.

\section{Conclusions}

The analysis of the current status of introducing the specialty "public management and administration" in educational process of the higher educational institutions give the ground for the following conclusions.

1. The revealed problems and contradictions that flow from the requirements and conditions of the labor market, cause the necessity of harmonization of legislation as to introduction of the new specialty "public management and administration" for compliance with the normative in the higher education sphere and national educational standards. The author's attempt to generalize the scientific terminology in the public management sphere gives the grounds to state that categorical apparatus needs the deep studies and essential improvement and rationing of the basic terms at legislative level.

2. Transfer to the new specialty needs the elaboration of the scientific approaches as to correlations between specializations of the specialty 074 "public management and administration" according to which the educational institutions will prepare specialists for management in the public sphere and the kinds of professional activity of graduates.

3. For today the node priorities of the university preparation of the higher education applicants in the public management sphere are the following: harmonization of standards of preparation of specialists on the new specialty "public management and administration" at the levels "bachelor", "master", $\mathrm{PhD}$ in the conditions of realization of the Ukrainian Law "On Higher Education"; necessity of revision of the full spectrum of existing programs and their adaptation to the content part of the requirements of the Association Agreement between Ukraine and EU; determination of the main priorities of the professional preparation of managerial staff.

The special attention must be paid to the questions of elaboration of the practically oriented learning complex of disciplines that will determine the further effective development of the specialty "public management and administration".

It is clear that these questions are debated and need for detailed scientific grounded study of the problem, deep content-analysis of the categorical apparatus, monitoring of the efficiency of introducing the specialty in educational process of higher educational institutions, determination of the content of professional specialization of the future specialist and his professional competence, financial grounding of the resource and organizational support of the scientific work on the public management and administration.

\section{Acknowledgements}

Author of the article find it necessary to name the native scientists whose works and personal contacts formed the scientific-methodological worldview of the author on the subject sphere of this article: V. Bakumenko, M. Belinskaya, L. Belova, K. Vaschenko, R. Voitovich, V. Gusev, D. Karamishev, A. Kolodiy, V. Lagutin, Y. Obolensky, L. Pashko, Y. Surmin, E. Romanenko, S. Teleshun, V. Fedorenko and others and express the gratitude to these scientists. 


\section{References}

[1] Zakon Ukraini "Pro vischu osvitu", 1556-VII, vid 01 lipnya 2014 roku (2014). Osvitniy portal. Available at: http://www.osvita.org.ua/pravo/law_05/part_05.html

[2] Pro zatverdzhennia pereliku haluzei znan i spetsialnostei, za yakymy zdiisniuietsia pidhotovka zdobuvachiv vyshchoi osvity vid 29 kvitnia 2015 roku № 266 (2015). Kabinetu Ministriv Ukrai’ny. Available at: http://www.kmu.gov.ua/control/ru/

[3] Pro osoblyvosti zaprovadzhennja pereliku galuzej znan' i special'nostej, za jakymy zdijsnjujet'sja pidgotovka zdobuvachiv vyshhoi' osvity, zatverdzhenogo postanovoju Kabinetu Ministriv Ukrai'ny vid 29 kvitnja 2015 roku № 266 (2015). Verhovna Rada Ukrai’ny. Available at: http://zakon5.rada.gov.ua/ laws/show/z1460-15

[4] Pollitt, C. (2004). Public Management Reform: A Comparative Analysis. Oxford: University Press, 12-13.

[5] Osborn, R. (2010). Tsyvylyzatsyya. Novaya ystoryya Zapadnoho myra. Moscow: AST, 764.

[6] Thompson, F. (1997). The New Public Management. Journal of Policy Analysis and Management, 16 (1), 165-176.

[7] Bakumenko, V. D. (2015). Publichne administruvannya yak protses viroblennya, priynyattya ta vikonannya upravlinskih rishen. Naukovi rozvidki z derzhavnogo ta munitsipalnogo upravlinnya, 1, 8-26.

[8] Kolodiy, A. (2011). Publichne vryaduvannya i publichne administruvannya. Entsyklopediya derzhavnoho upravlinnya u 8-my tomakh, Tom 8: Publichne vryaduvannya, L'viv: LRIDU NADU, 488-489.

[9] Melnik, R. S. (2013). Kategoriya "publichne upravlinnya" u noviy interpretatsiyi. Administrativne pravo i protses, $1,8-14$.

[10] Khomy, N. M. (Ed.) (2015). Novitnya politychna leksyka (neolohizmy, okazionalizmy ta inshi novotvory), navch. entsyklopedychnyy slovnyk-dovidnyk. L’viv: «Novyy svit - 2000», 490.

[11] Kovbasyuk, Yu. V., Romanyuk, S. A., Obolens'kiy, O. Yu. (Eds.) (2014). Publichne upravlinnya: shlyakhy rozvytku. Vol. 1. Kyiv: NADU, 150.

[12] Sharov, Yu. P. (2011). Publichne vryaduvannya i publichne administruvannya. Entsyklopediya derzhavnoho upravlinnya u 8-my tomakh. Tom 8: Publichne vryaduvannya. Lviv: LRIDU NADU, 491-493.

[13] The Bologna Declaration of 19 June 1999 (2003). Joint declaration of the European Ministers of Education, 3. Available at: http://www.magna-charta.org/resources/files/text-of-the-bologna-declaration

[14] Universitetska avtonomiya - zaporuka yakosti ukrainskoi osviti (2010). Available at: http://press. ukma.kiev.ua/index.php?option 